\title{
Crustacean invasions in the Estonian coastal sea
}

\author{
Kristjan Herkül $^{\mathrm{a}, \mathrm{b}, \bowtie}$, Jonne Kotta $^{\mathrm{a}}$, Teemar Püss ${ }^{\mathrm{a}}$, and Ilmar Kotta ${ }^{\mathrm{a}}$ \\ ${ }^{a}$ Estonian Marine Institute, University of Tartu, Mäealuse 10a, 12618 Tallinn, Estonia \\ ${ }^{\mathrm{b}}$ Institute of Ecology and Earth Sciences, University of Tartu, Vanemuise 46, 51014 Tartu, Estonia \\ $\bowtie$ Corresponding author, kristjan.herkyl@sea.ee
}

Received 1 April 2009, revised 18 May 2009

\begin{abstract}
In this paper we describe the invasion history of benthic crustacean species that have recently invaded the Estonian coastal sea. Physical characteristics of their habitat and communities associated with the invasive species were explored. The crustaceans Gammarus tigrinus, Chelicorophium curvispinum, Pontogammarus robustoides, and Paramysis intermedia are the most recent newcomers in the Estonian coastal sea. All these species have formed permanent populations and more aggressive species have likely caused significant shifts in the community structure and functioning. Besides the true invasive species, some native amphipod species have significantly expanded their range in the Baltic Sea. This group consists of rare or previously not spotted benthic invertebrate species in the northern Baltic Sea range such as Echinogammarus stoerensis, Calliopius laeviusculus, and Melita palmata.
\end{abstract}

Key words: Baltic Sea, benthic invertebrates, nonindigenous, Gammarus tigrinus, Chelicorophium curvispinum, Pontogammarus robustoides, Paramysis intermedia.

\section{INTRODUCTION}

Together with habitat loss and climate change, invasions of nonindigenous species are one of the most serious threats to global biodiversity. This human-aided process has initiated significant, unpredictable, and irreversible changes to both the abiotic and the biotic environment and has caused severe economic damage in a variety of waterbodies worldwide (e.g. Carlton, 1996; Vitousek et al., 1997; Sala et al., 2000). Concurrently with this global trend several new crustacean species have also been found in the Estonian coastal sea in recent years.

The gammarid amphipod Gammarus tigrinus Sexton originates from the North American coast of the Atlantic Ocean. The species was introduced to Europe probably in ballast water and was first discovered in England in 1931 (Chambers, 1977). Although G. tigrinus was found in the Baltic Sea already in 1975, its significant range expansion started in the 1990s (Jazdzewski et al., 2002, 2005; Szaniawska et al., 2003). In the northern Baltic Sea G. tigrinus was first found in the northern Gulf of Riga (Herkül et al., 2006) and the northern Gulf of Finland in 2003 (Pienimäki et al., 2004). In 2005, G. tigrinus was found in the Neva Estuary, the easternmost part of the Gulf of Finland (Berezina, 2007). This species has caused a significant decrease in the diversity and density of native 
amphipods in the southern Baltic Sea (Grabowski et al., 2006) and Estonian coastal sea (Kotta et al., 2006; Orav-Kotta et al., 2009).

The amphipod Chelicorophium curvispinum (Sars) originates from large rivers connected to the Black Sea and the Caspian Sea. It was found in the Baltic Sea already in the 1920s (Bij de Vaate et al., 2002). The species invaded to the Baltic and North seas through rivers and canals attached to the hulls of ships and in ballast water. Regardless of its long invasion history in the Baltic Sea, C. curvispinum was not found in the northern Baltic until 2005 when it was detected in the eastern part of the Estonian coast of the Gulf of Finland (Herkül \& Kotta, 2007). In the next year, 2006, C. curvispinum was found in Luga Bay, Russia (Malyavin et al., 2008).

Similarly to C.curvispinum, the gammarid amphipod Pontogammarus robustoides (Sars) originates from the lower reaches of Ponto-Caspian rivers and from brackish and freshwater lakes around the Black Sea (Bij de Vaate et al., 2002). In 1960-1961, the species was intentionally introduced into the Kaunas Water Reservoir on the Nemunas River, Lithuania (Bij de Vaate et al., 2002; Gumuliauskaite \& Arbačiauskas, 2008). It successfully spread in the Nemunas drainage system including the Curonian Lagoon of the Baltic Sea. In 1999 $P$. robustoides was first found in Neva Bay, the easternmost part of the Gulf of Finland (Panov et al., 2003) and in 2006, in Lake Ladoga (Kurashov \& Barbashova, 2008). In 2006 the species was recorded for the first time in the Estonian coastal sea. Similarly to G. tigrinus, P. robustoides has a potential to reduce the diversity and density of native gammarids (Panov et al., 2003; Gumuliauskaitė \& Arbačiauskas, 2008).

The mysids Paramysis intermedia (Czerniavsky) and P. lacustris (Czerniavsky) are native to rivers connected to the Caspian Sea and Black Sea (Birshteina et al., 1968). In the 1970s P. lacustris and P. intermedia were introduced to Lake Peipsi but neither of the species has been sighted later (Timm et al., 2001). Both species were also introduced to Lake Võrtsjärv, southern Estonia, in the 1970s, but only $P$. lacustris formed a permanent population there (Kangur et al., 2004). However, there is only a single record of $P$. lacustris in the Estonian coastal sea dating back to 1963 (Yarvekyulg, 1979). We are not aware of any successful introductions of $P$. intermedia in the Baltic Sea drainage area while P. lacustris inhabits the Curonian Lagoon, the southern Baltic Sea, already since the 1960s. In 2008 P. intermedia was found for the first time in the Baltic Sea. There were two separate records in 2008, one from the Gulf of Riga and the other from the eastern Gulf of Finland.

Besides the true invasive species this paper reports recent findings of rare gammarid amphipods in the northern Baltic Sea range. Echinogammarus stoerensis (Reid), Calliopius laeviusculus (Kröyer), and Melita palmata (Montagu) are found on the north-eastern coast of the Atlantic (Barnes, 1994; Hansson, 1998; BellanSantini \& Costello, 2001). There have been only a few documented records of E. stoerensis in the Baltic Sea region (Jazdzewski, 1976; Leineweber, 1985). The species was found for the first time in the Estonian coastal sea near Osmussaar Island, the western Gulf of Finland, in 2007. Melita palmata is known to inhabit the western and central Baltic (Yarvekyulg, 1979; Barnes, 1994; Hansson, 1998). 
In 2006, M. palmata was found for the first time in Estonia. According to Yarvekyulg (1979), C. laeviusculus is found from the southern Baltic Sea to the western part of the Gulf of Finland. From the Estonian coastal sea, documented records of C. laeviusculus near Hiiumaa Island date from 1963. There were no further records of $C$. laeviusculus until 2006 when the species was found in the western part of the Gulf of Finland and off western Saaremaa Island.

The aims of this study are to report (1) new data on the distribution and habitats of recently arrived nonindigenous amphipods (G. tigrinus, C. curvispinum, $P$. robustoides) in the Estonian coastal sea, (2) the first record of $P$. intermedia in the Baltic Sea, and (3) new findings of rare amphipod species (E. stoerensis, C. laeviusculus, M. palmata) in the Estonian coastal sea.

\section{MATERIAL AND METHODS}

Data from more than 6900 quantitative benthos samples collected from the Estonian coastal sea (Fig. 1) in 2003-2008 (databases of the Estonian Marine Institute) were used in this study. The data were obtained from macrozoobenthos and macrophytobenthos mapping studies, the Estonian coastal sea monitoring programme, and field experiments. All benthos samples were collected and analysed according to the HELCOM standards (HELCOM, 2006). Additionally, some semiquantitative

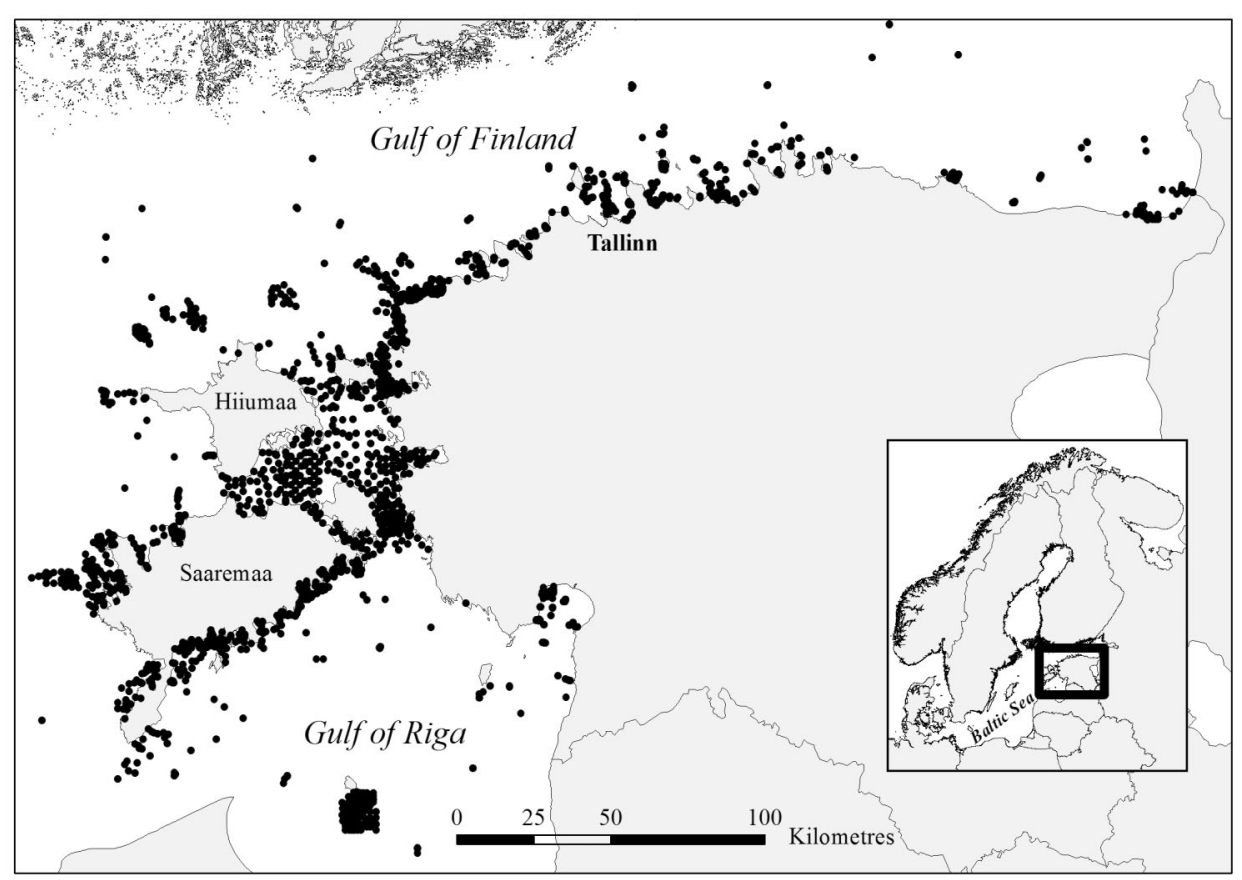

Fig. 1. Sampling stations in the Estonian coastal sea in 2003-2008. 
K. Herkül et al.

samples were collected with a hand net and Rass dredge in Narva Bay, the eastern Gulf of Finland, in 2008. All biomasses in this paper are represented in dry weight.

\section{RESULTS AND DISCUSSION}

Table 1 presents information on the first records of the crustaceans studied in the Estonian coastal waters and physical characteristics of their populations (biomass, abundance) and habitat (depth, sediment type).

In the Estonian coastal sea Gammarus tigrinus was first found in Kõiguste Bay, northern Gulf of Riga, in 2003 (Fig. 2) when the benthic colonization and community development were studied in a mesocosm experiment in the shallow water area of this bay. The alien amphipod had colonized several experimental mesocosms (Herkül et al., 2006), but despite intensive sampling throughout the ice-free season, the species was not observed in regular monitoring stations (Kotta et al., 2006). In the mesocosm experiment the abundance and biomass of G. tigrinus ranged between 100 and 800 ind. $\mathrm{m}^{-2}$ and 0.2 and $2.3 \mathrm{~g} \mathrm{~m}^{-2}$, respectively. In 2003 G. tigrinus was also found for the first time in the Gulf of Finland near Hamina and Turku (Pienimäki et al., 2004). In 2004 G. tigrinus had already spread all over Kõiguste Bay with densities up to 4700 ind. $\mathrm{m}^{-2}$ and biomass reaching $12.22 \mathrm{~g} \mathrm{~m}^{-2}$. In 2005 the alien amphipod was found all over the northern Gulf of Riga, throughout the southern coast of Saaremaa Island, and in Rame Bay, western mainland. By 2006 G. tigrinus had reached Pärnu Bay and the eastern bays of the West Estonian Archipelago Sea. The amphipod was first found in the western part of the Gulf of Finland in 2007 and in its central and eastern parts in 2008 (Fig. 2). By the end of 2008 G. tigrinus had been found from a total of 350 benthos samples from the Estonian coastal sea. Based on all the samples containing G. tigrinus, the amphipod's abundance varied between 0.118 and 5150 ind. $\mathrm{m}^{-2}$ and its biomass was from $<0.001$ to $12.22 \mathrm{~g} \mathrm{~m}^{-2}$. The average values of abundance and biomass were 418 ind. $\mathrm{m}^{-2}$ and $0.654 \mathrm{~g} \mathrm{~m}^{-2}$, respectively. The alien amphipod reached its maximum biomasses already in the second year of invasion in Kõiguste Bay in 2004. It inhabited a broad depth range from 0.2 to $20.5 \mathrm{~m}$, but the mean depth of the finds was only $1.7 \mathrm{~m}$ (Table 1 ). The species preferred sandy and silty sediments associated with charophytes, phanerogams (Myriophyllum spicatum L., Potamogeton pectinatus L.), and the green alga Cladophora glomerata (L.) Kützing. Invertebrate species most frequently cooccurring with G. tigrinus were chironomid larvae, the cockle Cerastoderma glaucum (Poiret), and the gastropod Theodoxus fluviatilis (L.). There is some circumstantial evidence that G. tigrinus is competitively superior over most other native gammarid species in European fresh and brackish waterbodies (e.g. Pinkster

et al., 1992; Grabowski et al., 2006). Similarly, we observed a significant decline of native gammarids associated with the invasion of G. tigrinus in the Estonian coastal range (Kotta et al., 2006). A recent experimental study on the feeding preferences and the aggressiveness of gammarid amphipods also corroborated these 


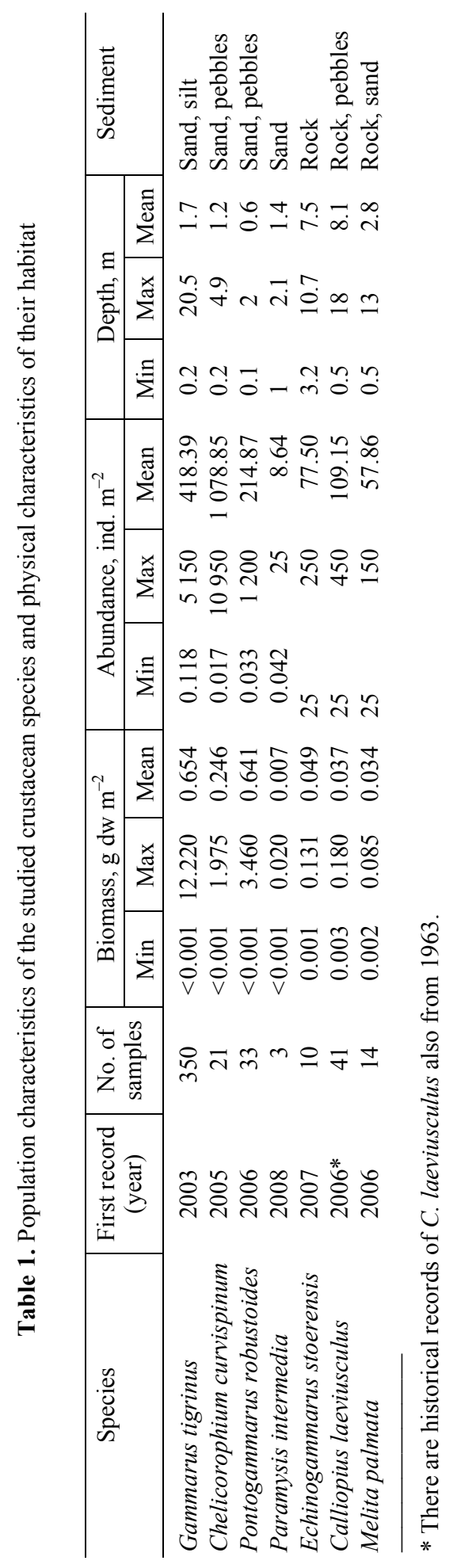




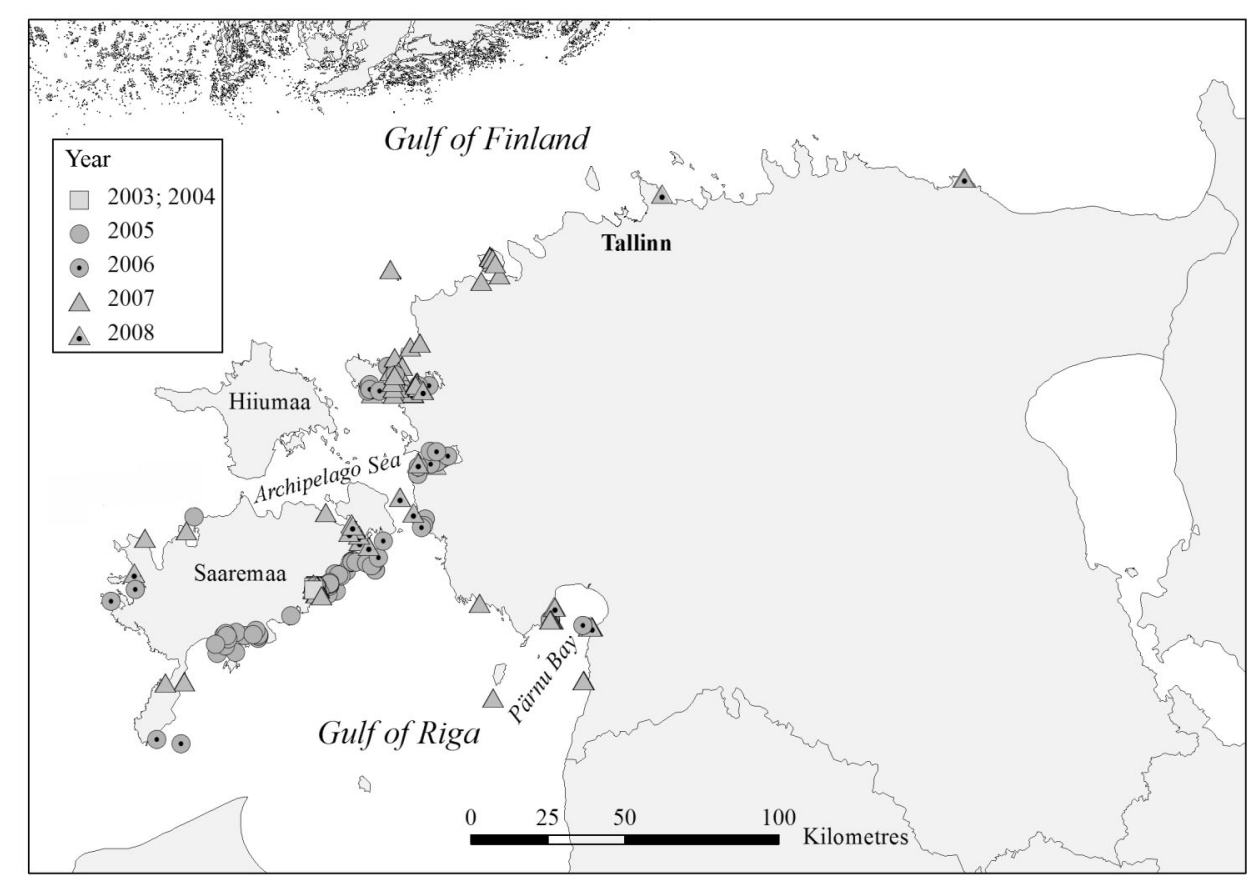

Fig. 2. Invasion and range expansion of Gammarus tigrinus in the Estonian coastal sea.

findings and we concluded that the competitive interaction between G. tigrinus and the native amphipods within the prevailing macrophyte communities is the likely explanation of the decline of the native gammarid amphipods after the establishment of G. tigrinus in the northern Baltic Sea (Orav-Kotta et al., 2009).

Chelicorophium curvispinum was found for the first time in the Estonian coastal sea near Sillamäe in Narva Bay, the eastern Gulf of Finland, in 2005. The salinity in the area is about 4.5. The species was observed in the depth range of 1 to $4.9 \mathrm{~m}$ in places where the bottom substrate was dominated by sand and boulders. The bottom vegetation was characterized by a belt of the green algae Cladophora rupestris (L.) Kützing and C. glomerata. The average abundance of C. curvispinum varied between 125 and 1425 ind. $\mathrm{m}^{-2}$ and its average biomass was $0.05-0.27 \mathrm{~g} \mathrm{~m}^{-2}$. The minimum and maximum densities were found at 4.9 and $3 \mathrm{~m}$ depths, respectively. After juveniles of gammarid amphipods, C. curvispinum was the second most abundant taxon at $3 \mathrm{~m}$ depth. By 2008 C. curvispinum was found some $3 \mathrm{~km}$ westwards and $15 \mathrm{~km}$ eastwards (mouth of the Narva River). Then its abundance and biomass reached 10950 ind. $\mathrm{m}^{-2}$ and $1.975 \mathrm{~g} \mathrm{~m}^{-2}$, respectively. The depth range at which C. curvispinum has been found is 0.2 to $4.9 \mathrm{~m}$ (Table 1). The nonindigenous amphipod co-occurred mainly with Gammarus spp., chironomid larvae, and another Ponto-Caspian invader in the region, P. robustoides. Cladophora glomerata and Ulva intestinalis (L.) Nees were the dominant macrophytobenthic species in the locations of C. curvispinum. At high densities C. curvispinum is known 
to reduce the species richness of macroinvertebrates and decreases, through high filtration capacity, total suspended matter. Additionally, by constructing tubes on solid substrate C. curvispinum may alter the physical properties of the benthic environment (Bij de Vaate et al., 2002). Because of the short invasion history and limited distribution of C. curvispinum in the Estonian coastal waters, we lack evidence for the negative effects of the species on local communities so far.

Pontogammarus robustoides was recorded for the first time in the Estonian coastal sea in Narva Bay, eastern Gulf of Finland, in 2006 (Fig. 3). The amphipod inhabited the sandy-pebbly seabed at $2 \mathrm{~m}$ depth, co-occurring with the amphipods Gammarus spp., Chelicorophium curvispinum, the barnacle Balanus improvisus Darwin, and chironomid larvae. Ulva intestinalis and Cladophora glomerata prevailed in phytobenthos. When first found in 2006, P. robustoides was present only in one sample. The abundance and biomass were 300 ind. $\mathrm{m}^{-2}$ and $0.698 \mathrm{~g} \mathrm{~m}^{-2}$, respectively. In 2007 and 2008 the invader was found ca. $7 \mathrm{~km}$ eastwards of the location of the first record. The abundance and biomass were up to 1200 ind. $\mathrm{m}^{-2}$ and $2.044 \mathrm{~g} \mathrm{~m}^{-2}$, respectively (Table 1). The amphipod co-occurred with the same benthic species as in 2006. In the northern Baltic Sea P. robustoides has a localized distribution. However, the species is very abundant in the southern Baltic Sea and is together with Obesogammarus crassus (Sars) the most invasive

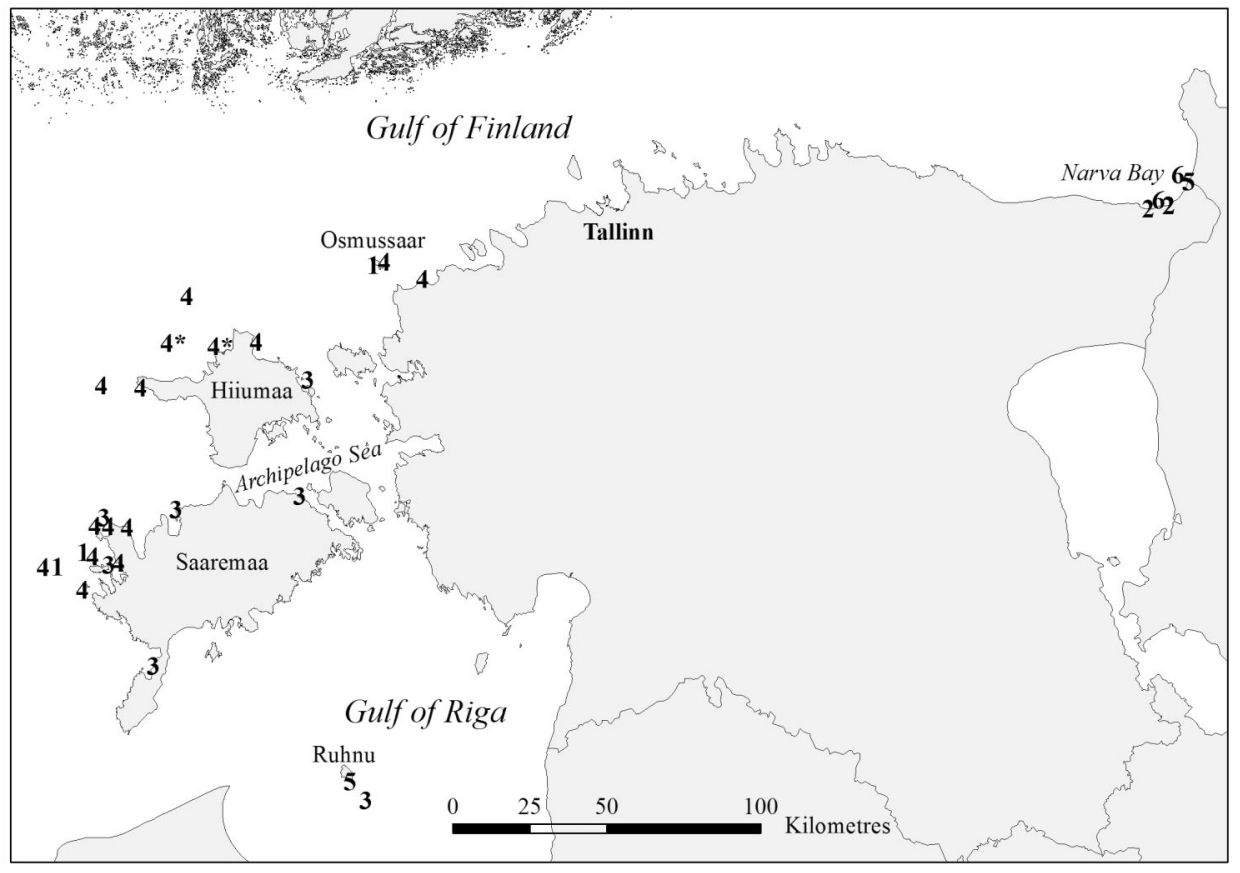

Fig. 3. Distribution of the studied crustacean species in the Estonian coastal range: 1 -Echinogammarus stoerensis, 2 - Pontogammarus robustoides, 3 -Melita palmata, 4 -Calliopius laeviusculus (* denotes historical records from 1963), 5-Paramysis intermedia, 6-Chelicorophium curvispinum. 
among gammarid amphipods (Grabowski et al., 2007). Thus, in a near future other major shifts in macrophyte-herbivore assemblages can be expected together with the retreat of G. tigrinus and the establishment of P. robustoides and $O$. crassus. As the effects of these species on native amphipods and macrophytes are not known in the northern Baltic Sea, it is difficult to predict the effects of the invasions on the ecosystem.

There were two parallel finds of Paramysis intermedia in 2008: near Ruhnu Island, the Gulf of Riga, and in the coastal sea adjacent to the mouth of the Narva River, the eastern Gulf of Finland (Fig. 3). These are the first records of the species in the Baltic Sea range. In the Narva River site, P. intermedia was found on a shallow $(1 \mathrm{~m})$ sandy bottom co-occurring with the other two Ponto-Caspian invaders, $C$. curvispinum and $P$. robustoides. In the Ruhnu Island site, $P$. intermedia was found at $2.1 \mathrm{~m}$ depth on a sandy-rocky bottom together with the gastropod T. fluviatilis, amphipods Gammarus spp., isopods Idotea spp., the barnacle B. improvisus, and chironomid larvae. Henn Timm (2007, pers. comm.) found unknown mysids from the Narva River in 2007. Later these animals were identified as $P$. intermedia. Although $P$. intermedia did not form a permanent population in Lake Peipsi after its deliberate introduction in the 1970s, the species might have survived in the Narva River and is currently invading the coastal sea. The invasion corridor of the Gulf of Riga population remains unknown. There are no documented ecological impacts of $P$. intermedia.

Echinogammarus stoerensis was found for the first time in the Estonian waters in 2007 near Osmussaar Island, the western Gulf of Finland, at $5 \mathrm{~m}$ depth on a rocky bottom (Fig. 3). The species was found only in one sample with the abundance and biomass of 50 ind. $\mathrm{m}^{-2}$ and $0.001 \mathrm{~g} \mathrm{~m}^{-2}$, respectively. The dominant species in the sample were the gastropods Theodoxus fluviatilis and Hydrobia ulvae (Pennant), the bivalve Macoma balthica (L.), and amphipods Gammarus spp. In 2008, E. stoerensis was found in several sampling sites near western Saaremaa Island in the depth range of $3.2-10.7 \mathrm{~m}$. These sites were characterized by a rocky seabed with the brown algae Pilayella littoralis (L.) Kjellman and Chorda filum (L.) Stackhouse dominating in the phytobenthos and the bivalve Mytilus trossulus Gould, the barnacle B. improvisus, amphipods Gammarus spp., and the isopod Jaera albifrons Leach being dominant invertebrates. The abundance and biomass of $E$. stoerensis reached 250 ind. $\mathrm{m}^{-2}$ and $0.131 \mathrm{~g} \mathrm{~m}^{-2}$, respectively (Table 1).

Calliopius laeviusculus was previously found in 1963 near Hiiumaa Island (Yarvekyulg, 1979). Since then there were no records of the species until 2006 when it was found in the western part of the Gulf of Finland (Fig. 3). Later on there were several finds near Osmussaar Island, Hiiumaa Island, and western Saaremaa Island in 2007-2008 (Fig. 3). The depth in the locations of C. laeviusculus varied between 0.5 and $18 \mathrm{~m}$ with the average being $8.1 \mathrm{~m}$. Rocky and pebbly substrate dominated with the brown alga $P$. littoralis and the red alga Ceramium spp. The bivalve M. trossulus, amphipods Gammarus spp., and the isopod J. albifrons were the dominant invertebrates found in the samples with C. laeviusculus. The abundance and biomass of C. laeviusculus reached 450 ind. $\mathrm{m}^{-2}$ and $0.180 \mathrm{~g} \mathrm{~m}^{-2}$, respectively (Table 1). 
Melita palmata was first found on the northwestern coast of Saaremaa Island in 2006 (Fig. 3). There were several additional records around Saaremaa Island, eastern Hiiumaa Island, and near Ruhnu Island in 2007-2008. The invertebrate was mainly found on a rocky and sandy seabed in the depth range of 0.5 to $13 \mathrm{~m}$ (Table 1). The dominating plant species in the locations of M. palmata were P. littoralis, Ceramium spp., and Cladophora spp. and of invertebrates Gammarus spp., Idotea spp., T. fluviatilis, and M. trossulus prevailed. The abundance and biomass of M. palmata were up to 150 ind. $\mathrm{m}^{-2}$ and $0.085 \mathrm{~g} \mathrm{~m}^{-2}$, respectively (Table 1).

To conclude, all crustacean amphipods that have recently invaded had formed permanent populations and most of them are commonly found all over the studied Estonian coastal sea. Due to their aggressiveness and high densities some of these species have probably caused significant shifts in the community structure and functioning. As we lack consistent time series and experimental studies it is difficult to say what factors are behind these recent invasions and range expansions. It is plausible, though, that recent changes in climate associated with milder winters have supported the blooms of filamentous algae throughout the Baltic Sea range. This together with prevailing westerlies and increased salinities has favoured the survival, reproduction, and eastward dispersal of phytophilous crustacean species.

\section{REFERENCES}

Barnes, R. S. K. 1994. The Brackish-water Fauna of Northwestern Europe: A Guide to Brackishwater Habitats, Ecology, and Macrofauna for Field Workers, Naturalists, and Students. Cambridge University Press, Cambridge.

Bellan-Santini, D. \& Costello, M. J. 2001. Amphipoda. In European Register of Marine Species: A Check-list of the Marine Species in Europe and a Bibliography of Guides to Their Identification (Costello, M. J. et al., eds). Collection Patrimoines Naturels, 50, 295-308.

Berezina, N. A. 2007. Expansion of the North American amphipod Gammarus tigrinus Sexton, 1939 to the Neva Estuary (easternmost Baltic Sea). Oceanologia, 49, 129-135.

Bij de Vaate, A., Jazdzewski, K., Ketelaars, H. A. M., Gollasch, S. \& Van der Velde, G. 2002. Geographical patterns in range extension of Ponto-Caspian macroinvertebrate species in Europe. Can. J. Fish. Aquat. Sci., 59, 1159-1174.

Birshteina, Ya. A., Vinogradova, L. G., Kondakova, N. N., Kun, M. S., Astahoboj, T. V. \& Romanovoj, N. N. 1968. Atlas of Invertebrates of the Caspian Sea. Moscow (in Russian).

Carlton, J. T. 1996. Pattern, process, and prediction in marine invasion ecology. Biol. Conserv., 78, 97-106.

Chambers, M. R. 1977. The population ecology of Gammarus tigrinus (Sexton) in the reed beds of the Tjeukemeer. Hydrobiologia, 53, 155-164.

Grabowski, M., Konopacka, A., Jazdzewski, K. \& Janowska, E. 2006. Invasions of alien gammarid species and retreat of natives in the Vistula Lagoon (Baltic Sea, Poland). Helgoland Mar. Res., 60, 90-97.

Grabowski, M., Jaždžewski, K. \& Konopacka, A. 2007. Alien Crustacea in Polish waters - Amphipoda. Aquat. Invasions, 2, 25-38.

Gumuliauskaite, S. \& Arbačiauskas, K. 2008. The impact of the invasive Ponto-Caspian amphipod Pontogammarus robustoides on littoral communities in Lithuanian lakes. Hydrobiologia, 599, 127-134. 
K. Herkül et al.

Hansson, H. G. 1998. NEAT (North East Atlantic Taxa): South Scandinavian marine Crustacea checklist. http://www.tmbl.gu.se/libdb/taxon/neat_pdf/NEAT*Crustacea.pdf (accessed 2008-05-01).

HELCOM. 2006. Manual for Marine Monitoring in the COMBINE Programme of HELCOM. $\mathrm{http}: / /$ sea.helcom.fi/Monas/CombineManual2/CombineHome.htm (accessed 2008-05-01).

Herkül, K. \& Kotta, J. 2007. New records of the amphipods Chelicorophium curvispinum, Gammarus tigrinus, G. duebeni, and G. lacustris in the Estonian coastal sea. Proc. Estonian Acad. Sci. Biol. Ecol., 56, 290-296.

Herkül, K., Kotta, J., Kotta, I. \& Orav-Kotta, H. 2006. Effects of physical disturbance, isolation and key macrozoobenthic species on community development, recolonisation and sedimentation processes. Oceanologia, 48, 267-282.

Jazdzewski, K. 1976. Notes on the occurrence and ecology of Chaetogammarus stoerensis (Reid, 1938) (Amphipoda) in the Baltic Sea. Crustaceana, 30, 33-38.

Jazdzewski, K., Konopacka, A. \& Grabowski, M. 2002. Four Ponto-Caspian and one American gammarid species (Crustacea, Amphipoda) recently invading Polish waters. Contrib. Zool., 71, 115-122.

Jazdzewski, K., Konopacka, A. \& Grabowski, M. 2005. Native and alien malacostracan Crustacea along the Polish Baltic Sea coast in the twentieth century. Ocean. Hydrobiol. Stud., 34, Suppl. 1, 175-193.

Kangur, K., Timm, H. \& Timm, T. 2004. Zoobenthos. In Lake Võrtsjärv (Haberman, J., Pihu, E. \& Raukas, A., eds), pp. 265-279, Estonian Encyclopaedia Publishers, Tallinn.

Kotta, J., Herkül, K., Kotta, I. \& Orav-Kotta, H. 2006. Invasion history and distribution of the key benthic alien invertebrate species in the Estonian coastal sea. EMI Rep. Ser., 14, 13-19.

Kurashov, E. A. \& Barbashova, M. A. 2008. First record of the invasive Ponto-Caspian amphipod Pontogammarus robustoides G.O. Sars, 1894 from Lake Ladoga, Russia. Aquat. Invasions, 3, 253-256.

Leineweber, P. 1985. The life-cycles of four amphipod species in the Kattegat. Holarct. Ecol., 8, $165-174$.

Malyavin, S. A., Berezina, N. A. \& Khvang, D. S. 2008. Finding of Chelicorophium curvispinum (Amphipoda, Crustacea) in the Gulf of Finland, Baltic Sea. Zool. Zh., 87, 643-649 (in Russian).

Orav-Kotta, H., Kotta, J., Herkül, K., Kotta, I. \& Paalme, T. 2009. Seasonal variability in the grazing potential of the invasive amphipod Gammarus tigrinus and the native amphipod Gammarus salinus in the northern Baltic Sea. Biol. Invasions, 11, 597-608.

Panov, V. E., Bychenkov, D. E., Berezina, N. A. \& Maximov, A. A. 2003. Alien species introductions in the eastern Gulf of Finland: current state and possible management options. Proc. Estonian Acad. Sci. Biol. Ecol., 52, 254-267.

Pienimäki, M., Helavuori, M. \& Leppäkoski, E. 2004. First findings of the North American amphipod Gammarus tigrinus Sexton, 1939 along the Finnish coast. Mem. Soc. Fauna Flora Fenn., 80, 17-19.

Pinkster, S., Scheepmaker, M., Platvoet, D. \& Broodbakker, N. 1992. Drastic changes in the amphipod fauna (Crustacea) of Dutch inland water during the last 25 years. Bijdr. Dierk., 61, 193-204.

Sala, O. E., Chapin, F. S., III, Armesto, J. J., Berlow, E., Bloomfield, J., Dirzo, R., Huber-Sanwald, E., Huenneke, L. F., Jackson, R. B., Kinzig, A., Leemans, R., Lodge, D. M., Mooney, H. A., Oesterheld, M., Poff, N. L., Sykes, M. T., Walker, B. H., Walker, M. \& Wall, D. H. 2000. Global biodiversity scenarios for the year 2100. Science, 287, 1770-1774.

Szaniawska, A., Łapucki, T. \& Normant, M. 2003. The invasive amphipod Gammarus tigrinus Sexton, 1939, in Puck Bay. Oceanologia, 45, 507-510.

Timm, T., Kangur, K., Timm, H. \& Timm, V. 2001. Zoobenthos. In Lake Peipsi. Flora and Fauna (Pihu, E. \& Haberman, J., eds), pp. 82-99. Sulemees Publishers, Tallinn.

Vitousek, P. M., Mooney, H. A., Lubchenco, J. \& Melillo, J. M. 1997. Human domination of Earth's ecosystems. Science, 277, 494-499.

Yarvekyulg, A. 1979. The Benthic Fauna in the Eastern Part of the Baltic Sea. Valgus, Tallinn (in Russian). 


\title{
Uute ja haruldaste vähiliikide levik Eesti rannikumeres
}

\author{
Kristjan Herkül, Jonne Kotta, Teemar Püss ja Ilmar Kotta
}

Kirpvähilised Gammarus tigrinus ja Pontogammarus robustoides, kaspia kootvähk Chelicorophium curvispinum ning müsiid Paramysis intermedia on Eesti rannikumere kõige uuemad võõrliigid, kes leiti esmakordselt vastavalt 2003., 2006., 2005. ja 2008. aastal. Lisaks võõrliikidele leiti aastail 2006-2008 Eesti rannikumerest kolm Läänemere põhjaosas harva esinevat kirpvähilist - Echinogammarus stoerensis, Melita palmata ja Calliopius laeviusculus. Kirpvähiliste E. stoerensis ja M. palmata puhul oli tegu esmaleidudega Eestis, kirpvähilist $C$. laeviusculus on varem leitud 1963. aastal. Artiklis on esitatud uusimad andmed võõrliikidest vähkide ja harva esinevate kirpvähiliste levikust ning elupaikadest aastatel 20032008. 